\section{Replantation as Treatment for Extrusive Luxation}

Elizane Ferreira Hamanaka, Lamis Meorin Nogueira, Willian Ricardo Pires, Sônia Regina Panzarini, Wilson Roberto Poi, Celso Koogi Sonoda
Department of Surgery and Integrated Clinics, Araçatuba Dental School, UNESP - Universidade Estadual

Paulista, Araçatuba, SP, Brazil

Correspondence: Prof. Dr. Celso Koogi Sonoda, Rua José Bonifácio

1193, 16015-050 Araçatuba, SP,

Brasil. Tel: +55-18-3636-3240.

e-mail: sonoda@foa.unesp.br
In the treatment of extrusive luxation cases, it is important that the repositioning of extruded tooth in the socket is done as soon as possible. If this does not occur, periapical clot becomes organized and makes replantation difficult reposition. In this article the patient referred to the Clinics for dental trauma sustaining extrusive luxation of the maxillary right central incisor. The patient reported having suffered a bicycle accident 12 days before, which caused traumatic tooth injuries. The repositioning was attempted without success and an alternative form of treatment was necessary to solve the case. Intentional tooth replantation, which is the deliberate extraction of the tooth and its replantation, was indicated. This technique allows clot removal and correct repositioning of the extruded tooth. Care should be taken as endodontic treatment is required for the prevention of subsequent infection-related resorption. Intracanal dressing with calcium hydroxide was used for 30 days before final root filling. Splint, systemic antibiotics and avoidance of further damage to the root surface is also important. After 49 months, showed clinical and radiographic characteristics of normality and demonstrates the availability of this technique to adversity in trauma.
Key Words: intentional replantation, extrusive luxation, calcium hydroxide.

\section{Introduction}

Dental luxation occurs more frequently in the primary dentition and coronal fractures are more common in permanent dentition. In dental luxation, periodontal ligament, cementum and pulp tissue are compromised. The occurrence of root resorption depends on the severity of damage on these structures. In permanent teeth, they are divided into subluxation, extrusive luxation, lateral luxation, avulsion and intrusive luxation (1).

Compared to intrusion and avulsion, extrusive luxation is characterized by less damage to the periodontium. The clinical aspect is an elongated tooth and excessive mobility. An increase in the apical periodontal ligament space may be observed radiographically (2). The recommended treatment is reposition of the tooth as soon as possible, use of splints, endodontic treatment, and clinical and radiographic control (3). However, it is possible that the patient ignores the need for immediate treatment, postponing it for days or weeks, making it difficult to reposition the extruded tooth. In such cases, before a late treatment due to blockage by blood clot, another alternative should be considered (4).

Although not commonly used, a treatment option for these cases may be intentional replantation. This technique consists in the extraction followed by reinsertion of the tooth in its source socket $(4,5)$ and is considered as an option for adverse situations $(6,7)$.

This case report aims to demonstrate the effectiveness of intentional tooth replantation in a late treatment of extrusive luxation.

\section{Case Report}

A 16-year-old male patient was referred to the Department of Surgery and Integrated Clinics of Araçatuba Dental School, UNESP, Brazil, with dental traumatism. After questioning, the patient reported he had suffered a bicycle accident 12 days before and had dental injuries. The intraoral clinical examination showed that the maxillary left central incisor had enamel/dentin fracture in the incisal edge. The maxillary right central incisor was $5 \mathrm{~mm}$ extruded relation to the maxillary left central incisor (Fig. 1A), presented grade II mobility and sensitivity to touch. Radiographically, it was observed that the right central incisor had the periodontal ligament space increased in the periapical region (Fig. 2A). Clinical examination showed that tooth repositioning by manual procedure was not possible. Thus, the alternative treatment plan consisted of repositioning the tooth extruded by deliberate replantation and followed by endodontic treatment. The procedure consisted in prophylaxis, syndesmotomy (Fig. 1B) followed by extraction of the maxillary right central incisor with forceps (Figs. 1C and D). Care was taken not to damage the root surface and the extracted tooth was kept in saline solution (Fig. 1E). Meticulous curettage and irrigation with saline solution of the socket was carried out to remove the blood clot (Fig. 1F). The clot adhered to the apical portion of the root was carefully removed with gauze soaked in saline solution (Fig. 1E). Eight minutes after the extraction, replantation was performed. The tooth was repositioned carefully seeking alignment with the incisal 
edge of the maxillary left central incisor and avoiding excessive compression of the root into its socket (Fig. 1G).

Splinting was carried out with orthodontic wire $0.7 \mathrm{~mm}$, fixed with $0.20 \mathrm{~mm}$ orthodontic wires (Dental Morelli Ltda, Sorocaba, SP, Brazil) to pre-existing brackets (Fig. 1H) and maintained for 15 days. Radiograph was taken to check the correct repositioning (Fig. 2B). Occlusal adjustment was made to prevent occusal traumatic interference. Amoxicillin $500 \mathrm{mg}$, every $8 \mathrm{~h}$ for 7 days and daily mouthwash with $0.12 \%$ chlorhexidine digluconate was prescribed. The endodontic treatment of the maxillary right central incisor was initiated seven days after replantation. Intracanal dressing with calcium hydroxide was used and final root filling with gutta-percha points and a calcium hydroxidebased sealer (Selapex; Sybron Endo, Orange, CA, USA) was made after 30 days. The maxillary left central incisor was restored with composite resin (Filtek Z350 XT; 3M ESPE, Sumaré, SP, Brazil). It was recommended to the patient to delay the orthodontic treatment for at least 1 year. The clinical and radiographic follow-up at 38 months showed that the maxillary right central incisor did not present mobility, root resorption or associated pain (Figs. $1 \mathrm{I}$ and 2C). Esthetics and occlusal function were also preserved.
The same characteristics were observed 49 months after completion of the treatment (Figs. 3A and B).

\section{Discussion}

When the extruded root portion is significant, it is important to accomplish the repositioning to recover the deployment of the root and avoid the resection of part of the crown for the occlusal adjustment. For this, it is important that the repositioning is carried out quickly and may be accomplished by careful manual compression of the tooth in the socket (3). In this clinical case it was not possible, since the patient showed up for treatment 12 days after the trauma. In this period, the periapical blood clot looks more organized and the repositioning is difficult. Therefore, other treatment option was planned taking into consideration a technique that presents less risk of damage to the root surface. According Martins et al. (4), the excessive tooth mobility and the possibility of further trauma, repositioning through orthodontic forces was discarded. It was then decided for intentional replantation, consisting in a similar technique to the one performed in the replantation of avulsed teeth by trauma $(4,7)$. As the periodontal fibers tend to be broken or stretched when
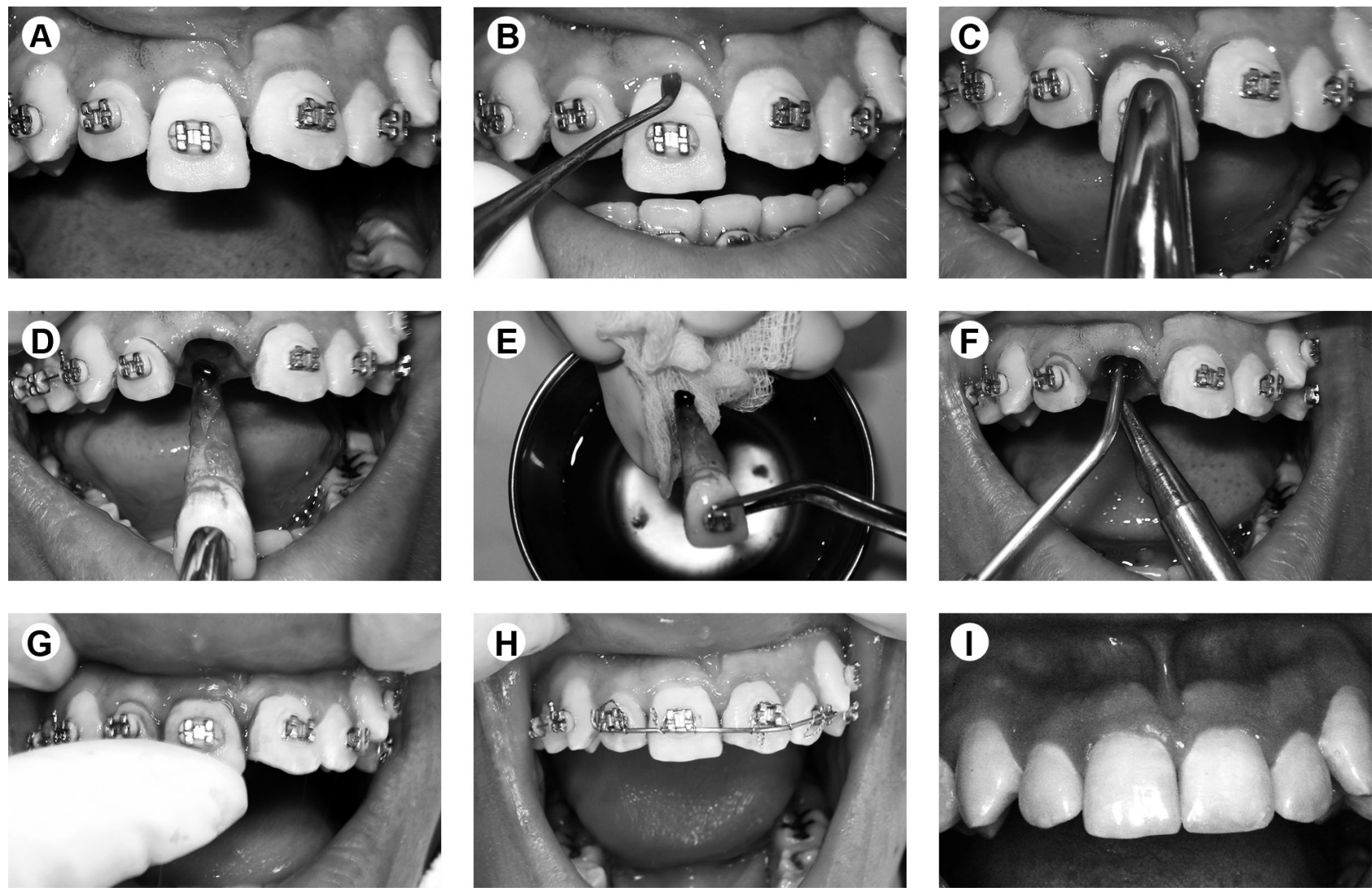

Figure 1. A: Initial intraoral picture showing the extrusion of the tooth 11. B: Syndesmotomy. C: Crown secured with forceps to prevent damage to the cervical region of the root. D: Extracted tooth showing the clot in the root apex. E: Clot removal from the root with gauze soaked in saline solution. F: lrrigation and suction to remove the clot from the socket. G: Tooth replanted and repositioned with slightly finger pressure. H: Orthodontic wire splint fixed on brackets. 1: Clinical condition at 37 months after treatment. 
the tooth has extruded $(1,2)$, the procedure for extraction becomes less traumatic, favoring the indication of this technique.

There are reports of favorable outcomes from intentional replantation in various situations (4-8), suggesting that this procedure is predictable and reliable, and should be considered more often as a method of treatment to keep the natural dentition. This procedure would be contraindicated in the presence of periodontal disease associated with tooth mobility, extensive caries, gingival inflammation and furcation involvement $(1,3)$. The failure of the treated teeth is represented by the root resorption resulting from damage in the periodontal ligament (9). In the present case, there was no exposure of the periodontal ligament of the cervical region to the oral environment. Probably there was no disruption of the gingival attachment after trauma. It is important that the factors influencing the vitality maintenance of this structure are observed (4). One should avoid a period of over $20 \mathrm{~min}$ out of the oral cavity (3), prevent mechanical damage to the root surface (10) to maintain hydration of the periodontal ligament of the tooth extracted using a storage medium and, if necessary, splint should be used after replantation (11), systemic antibiotics to prevent contamination could be prescribed (3). Because it is an intentional replantation procedure, control of these factors is favored. The time spent in the extra-alveolar environment and the likelihood of contamination is minimal, contributing to the repair (12). If these precautions are not respected, root resorption and ankylosis can be observed within 2 months. In most cases the resorption is diagnosed within the first 2 years (13) and in rare cases in 5 to 10 years (14).

Rupture of the apical nerve vessel bundle after extrusion may cause pulp necrosis. Endodontic treatment
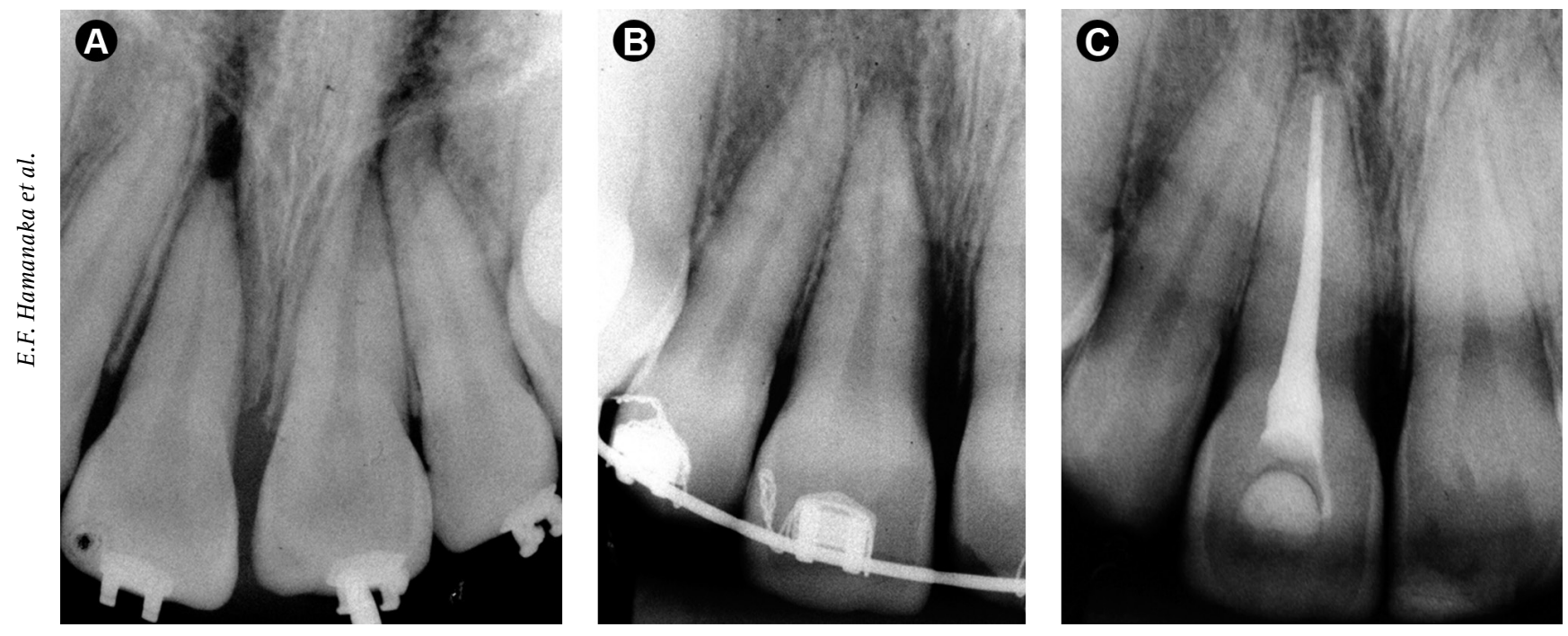

Figure 2. A: Initial periapical radiograph. Periapical region increased in the periodontal ligament space of the maxillary right central incisor B: Radiographic image of the tooth after replantation. C: Control radiograph at 38 months after treatment showing the integrity of the root surface and periodontal ligament space.
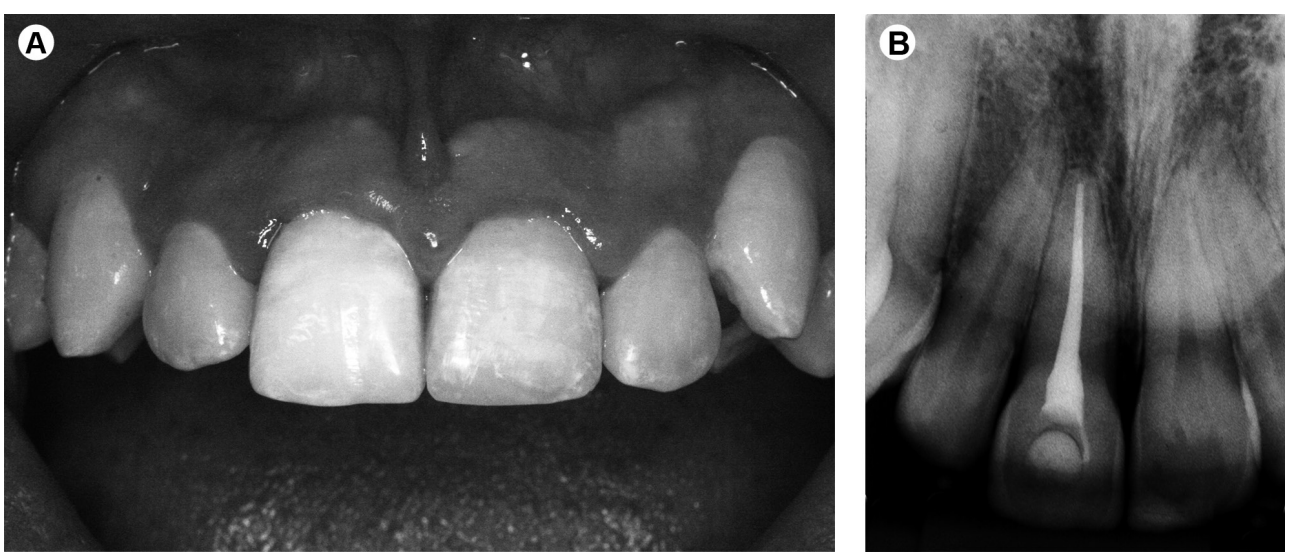

Figure 3. Clinical (A) and radiographic (B) aspect of the tooth at 49 months after treatment. 
is a required step for the prevention of subsequent infection-related resorption (15). Calcium hydroxide exerts effective inflammatory resorption control. According to the literature, the alkaline $\mathrm{pH}$ of calcium hydroxide plays an antimicrobial role in the root canal and blocks the evolution of infectious processes. Additionally, toxins produced by bacteria are denatured by the action of calcium hydroxide (16). The sum of these effects promotes root canal cleaning, which minimizes the occurrence of inflammatory resorption (17). In this case, use of calcium hydroxide for 30 days was effective since root resorption was not observed. Frequent calcium hydroxide fillings should be avoided because it can lead to the degeneration of collagen fibers in root dentin, thus increasing fracture susceptibility (18).

The good clinical and radiographic outcomes obtained after 49 months of follow-up enable indication of an intentional replantation of single-rooted teeth with extrusive luxation if the immediate treatment cannot be performed.

\section{Resumo}

No tratamento de casos de luxação extrusiva é importante que o reposicionamento do dente extruído em seu alvéolo seja feito o mais rápido possível. Se isso não ocorrer, o coágulo periapical se torna organizado e dificulta a reposição. Neste artigo, o paciente encaminhado para a clínica de traumatismo dentário apresentava luxação extrusiva do dente 11. 0 paciente relatou que havia sofrido um acidente de bicicleta 12 dias antes e teve lesões dentárias. Tentou-se fazer o reposicionamento sem sucesso e uma forma alternativa de tratamento foi necessária para resolver o caso. Reimplante intencional, que é a extração do dente e seu reimplante de forma proposital, foi indicado. Esta técnica permite a remoção do coágulo e o reposicionamento correto do dente extruído. Cuidado deve ser observado quanto ao tratamento endodôntico, para a prevenção de uma reabsorção relacionada a uma infecção. Curativo de demora com hidróxido de cálcio foi realizado por 30 dias antes da obturação final. Contenção, antibióticos sistêmicos e evitar maiores danos à superfície da raiz também são importantes. 0 controle de 38 meses mostrou características clínicas e radiográficas de normalidade $\mathrm{e}$ demonstra a disponibilidade desta técnica para a adversidade no trauma.

\section{References}

1. Andreasen FM, Andreasen J0, Andersson L. Luxation Injuries of Permanent Teeth: General Findings. In: Textbook and Color Atlas of Traumatic Injuries to the Teeth. Andreasen J0, Andreasen FM,
Andersson L (Editors). 4th ed. 0xford: Blackwell/Munksgaard; 2007. p 372-403.

2. Andreasen FM, Andreasen JO, Andersson L. Extrusive luxation and lateral luxation. In: Textbook and Color Atlas of Traumatic Injuries to the Teeth. Andreasen J0, Andreasen FM, Andersson L (Editors). 4th ed. Oxford: Blackwell/Munksgaard; 2007. p 411-427.

3. Diangelis AJ, Andreasen J0, Ebeleseder KA, Kenny DJ, Trope M,

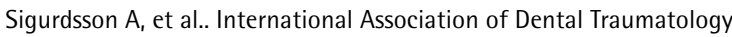
guidelines for the management of traumatic dental injuries: 1. Fractures and luxations of permanent teeth. Dent Traumatol. 2012; 28:2-12.

4. Martins WD, Westphalen VP, Perin CP, Da Silva Neto UX, Westphalen FH. Treatment of extrusive luxation by intentional replantation. Int J Paediatr Dent 2007;17:134-138.

5. Moura LF, Lima MD, Moura MS, Carvalho PV, Cravinhos JC, Carvalho $\mathrm{CM}$. Treatment of a crown-root fracture with intentional replantation - case report with 16-year follow-up. Int Endod J 2012;45:955-960.

6. Wolcott J, Rossman LE. Intentional replantation of endodontically treated teeth: an update. Compend Contin Educ Dent 2003;24:68-72.

7. Kratchman S. Intentional replantation. Dent Clin North Am 1997;41:603-617.

8. Dogan MC, Akgun EO, Yoldas HO. Adhesive tooth fragment reattachment with intentional replantation: 36-month follow-up. Dent Traumatol 2013;29:238-242.

9. Rouhani $A$, Javidi $B$, Habibi $M$, Jafarzadeh $H$. Intentional replantation: a procedure as a last resort. J Contemp Dent Pract 2011;12:486-492.

10. Andreasen J0. Analysis of pathogenesis and topography of replacement root resorption (ankylosis) after replantation of mature permanent incisors in monkeys. Swed Dent J 1980;4:231-240.

11. Niemczyk SP. Re-inventing intentional replantation: a modification of the technique. Pract Proced Aesthet Dent 2001;13:433-439.

12. Nuzzolese $E$, Cirulli N, Lepore MM, D'Amore A. Intentional dental reimplantation: a case report. J Contemp Dent Pract 2004;5:121-130.

13. Aqrabawi J. Five-year follow-up of successful intentional replantation. Dent Update 1999;26:388-390.

14. Andreasen JO, Borum MK, Jacobsen HL, Andreasen FM. Replantation of 400 avulsed permanent incisors. 4. Factors related to periodontal ligament healing. Endod Dent Traumatol 1995;11:76-89.

15. Andersson L, Andreasen JO, Day P, Heithersay G, Trope M, Diangelis AJ, et al.. International Association of Dental Traumatology guidelines for the management of traumatic dental injuries: 2 . Avulsion of permanent teeth. Dent Traumatol 2012;28:88-96.

16. Estrela C, Holland R. Calcium hydroxide: study based on scientific evidences. J Appl Oral Sci 2003;11:269-282.

17. Trope M. Clinical management of the avulsed tooth: present strategies and future directions. Dent Traumatol 2002;18:1-11.

18. Andreasen JO, Farik B, Munksgaard EC. Long-term calcium hydroxide as a root canal dressing may increase risk of root fracture. Dent Traumatol 2002;18:134-137. 